\title{
YOUTH UNEMPLOYMENT: WHAT ROLE CAN CORPORATE SOCIAL RESPONSIBILITY (CSR) PLAY IN CURBING THIS SOCIAL ILL IN SWAZILAND (ESWATINI) AND SOUTH AFRICA?
}

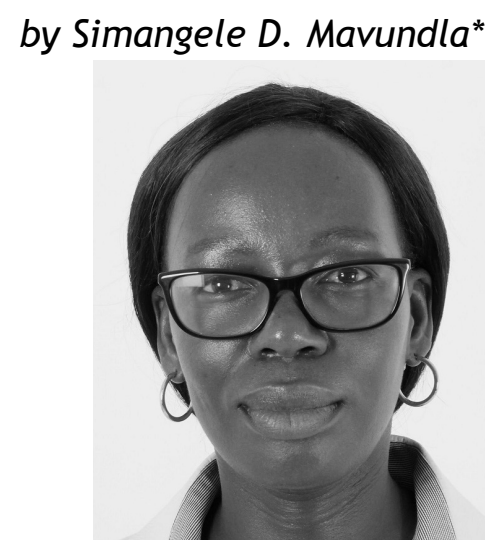

\section{Background on youth Employment in South Africa and Eswatini ${ }^{1}$}

\subsection{Definition of youth}

In 2006 the African Union adopted a policy framework (not a convention) in the form of the AYC, which mandates signatory States to advance youth development in their respective countries. ${ }^{2}$ The AYC

* This profound academic opinion advocates for youth employment by clearly arguing that even though the African Youth Charter (AYC) is not binding on states in as much as on corporates/businesses, at international law these same corporates/businesses have a role to play in ensuring that youth unemployment is curbed through invoking Corporate Social Responsibility (CSR). It will be argued that CSR is no longer only associated with philanthropy, but it is now part and parcel of promoting and protecting human rights in communities where businesses operate, such that they cannot turn a blind eye to social ills such as youth unemployment.

1 On 19 April 2018, the King of Swaziland or Eswatini unilaterally changed the name of the country from the Kingdom of Swaziland to Kingdom of Eswatini through Legal Notice 80 of 2018. The Notice stipulates in section 3 that 'reference in any written law or international agreement or legal document to Swaziland should be read and construed as reference to Eswatini.

2 Adopted by the Executive Council at its 6th Ordinary Session in Banjul in June 2006. The African Youth Charter has 42 signatory countries, 38 of which have ratified and only 3 are yet to sign and ratify. See https://www.africa-youth.org/ frameworks/african-youth-charter/ (accessed 27 August 2018). 
as a continental framework provides governments and stakeholders with ways in which programmes and strategic plans central to youth rights, duties and freedoms can be shaped and or formulated. ${ }^{3}$ The African Youth Charter defines a youth as a person who is between the age of 15 and 35 years. ${ }^{4}$ In South Africa, a youth is defined in line with the definition of the AYC as a person from the age of 14 to 35 years. ${ }^{5}$ This definition coincides with Eswatini's definition of a youth. ${ }^{6}$

\subsection{The rationale for the study}

The rationale for studying the two countries is based on the fact that Eswatini is neighbouring South Africa and is frequently compared to South Africa, it's much larger neighbour on which it is significantly reliant for its current GDP. Since the two countries are neighbours, there is a strong likelihood that the youth may migrate from one country to the other in search of greener pastures. However, the migration will be a one way if one country has no development prospects attracting the youth. Secondly, there is a lack of youth involvement in the two countries which is primarily manifested in high youth unemployment rates in both countries. This is a cause for concern, hence the need to find youth-specific interventions which can ensure that the youth in Eswatini and South Africa actively participate in nation-building and the economy. Lastly, CSR is canvassed as one intervention which could be used to ensure that the youth finds employment.

\subsection{Youth population}

South Africa's population is largely made up of young people, ranging from the age of 15 and 35 years, who constitute about $36.2 \%$ of its population. ${ }^{7}$ of the total population. Like South Africa, the population of Eswatini is youthful, with $39 \%$ of the population between the ages of $15-34$, and a total of $79 \%$ under the age of $35 .^{8}$ The implication of the youth bulge can either be an opportunity for growth or a ticking

3 The African Youth Charter (AYC) 2006 http://www.un.org/en/africa/osaa/pdf/ au/african_youth_charter_2006.pdf (accessed 28 September 2017).

4 The African Youth Charter (AYC), as adopted by the Executive Council at its 6th Ordinary Session in Banjul in June 2006, definition section.

5 The South African National Youth Policy (NYP) 2015 - 2020, 10.

6 Swaziland's National Youth Policy (SNYP) 2009.

7 Statistics South Africa, Community Survey 2016 statistic release http://cs2016. statssa.gov.za/wp-content/uploads/2016/07/NT-30-06-2016-RELEASE-for-CS2016-_Statistical-releas_1-July-2016.pdf (accessed 28 August 2018).

8 UNFPA, Swaziland state of the youth report $201511 \mathrm{http}: / /$ swaziland.unfpa.org/ sites/default/files/pub-pdf/Youth\%20Report\%202015\%20with\%20covers.pdf (accessed 28 August 2018). 
time bomb if not harnessed appropriately. ${ }^{9}$ In this regard, the South African National Youth Policy (NYP) reveals that there are challenges stopping the youth from participating in the mainstream economy meaningfully; and these are joblessness, inequalities and poverty. ${ }^{10}$

The policy provides that if the challenges are not addressed, the socio-economic effects of youth unemployment will be hard to deal with, something which the country cannot afford to ignore. The effects will include a poorly performing economy, increased crime, extreme joblessness and poverty, and increased potential for political instability. ${ }^{11}$ More or less the same challenges are attributable to Eswatini which has high rates of poverty, a decline in the strength of family structures, challenges with access to education, low employment, HIV/AIDS, access to family planning and youth-friendly sexual and reproductive health services, drug and alcohol use, gender inequality, violence, and crime. ${ }^{12}$

\subsection{Youth unemployment}

South Africa and Eswatini are grappling with high rates of youth unemployment. The labour force survey of June 2014 provides that in South Africa $36.1 \%$ of young people between the ages of 15 and 35 were unemployed, whereas the total unemployment rate for the country stood at $24.3 \%$, females accounting for $26.6 \%$ compared to males at $22.4 \% .{ }^{13}$ According to the Swaziland labour survey of 2010 , the unemployment rate for youth aged between $15-24$ was $53.3 \%$, and more women were unemployed, with overall unemployment rates for females sitting at $47.4 \%$ as compared to $33.6 \%$ for males. ${ }^{14}$

9 T Tlou, The Youth Bulge Theory - assessing its implications for South Africa (2014) http: / / www.transconflict.com/2014/12/youth-bulge-theory-assessing-imp lications-current-confrontation-youth-state-south-africa-212/ (accessed 29 September 2017). See also K Ighobor Africa's youth: a 'ticking time bomb' or an opportunity? (2013) http: / / www.un.org/africarenewal/magazine/may-2013/ africa's-youth-“ticking-time-bomb"-or-opportunity (accessed 29 September 2017).

10 NYP (n 5) 11

11 As above.

12 UNFPA (n 8) 41. The report provides that 'crime, combined with the unemployment situation in the country and the challenges with education, presents a picture of young people in Swaziland who may be contravening the law as an outcome of their educational and socioeconomic status.'

13 Statistic South Africa, Quarterly labour force survey 4 (2014) http://www. statssa.gov.za/?p=2951 (accessed 28 August 2018). See also, the South African NYP 20203.

14 Ministry of Labour and Social Security, Swaziland integrated labour force survey (2010) http://www.swazistats.org.sz/images/reports/Labour\%20Force\%20Survey \%20Report\%202010.pdf (accessed 29 August 2018). See also, Mavundla (n 8) 35-36. 
However, the statistics for 2017 revealed that in South Africa youth unemployment rose from $54 \%$ to $56 \% .^{15}$ Meanwhile, the statistics for Eswatini revealed that the unemployment rate rose from $40.6 \%$ in 2011 to $53 \%$ in $2017 .{ }^{16}$ This shows that there is an urgent need to find new ways which are innovative to address youth unemployment in both countries. The youth has vitality and if appropriately harnessed the youth can be utilised in order to bring about societal change, or used in nation building and development. However, the prevailing youth unemployment situation has left the majority of the youth idle and this is a challenge which governments cannot resolve alone. For youth employment to become a reality, the impetus is high for the governments of the two countries and the private sector to work together in order to resolve the challenge of youth unemployment.

Resolving youth unemployment will have a positive impact on other societal challenges that both countries continue to experience such as rural-urban migration, as well as informal settlements. Young people are less likely to move from rural areas in search for better, higher-paying jobs in the cities when there are attractive employment opportunities in the communities where they were raised. According to Uddin and another, the large number of unemployed youth could be capable of undermining democratic practices should they be engaged by the political class for clandestine activities. ${ }^{17}$ Therefore, youth unemployment must be tackled because if it continues it may lead to political instability and economic chaos; youth migration to other countries in search of greener pastures; and violence against girls and/or women. Researchers such as Henrics as cited in Uddin asserts that, low opportunities for young graduates create the problem of violence due to lack of job and idleness because without jobs they will not be able to play a useful role in the society. ${ }^{18}$

\section{$2 \quad$ National laws and policies on youth employment}

Discussed below are the law and policy frameworks for both countries, Eswatini and South Africa, which tackle youth unemployment.

L Peyper, Youth vulnerable as unemployment stays at the highest rate since 2003 (2017)https: / / www. fin24.com/Economy/youth-vulnerable-as-unemploymentstays-at-highest-rate-since-2003-20170807 (accessed 30 August 2018).

16 As above.

17 PSO Uddin and OO Uddin, 'Causes, effects and solutions to youth unemployment problems in Nigeria' (2013) Scholarlink Research Institute Journal at 397. 


\subsection{Laws and policies on youth employment in Eswatini}

The Constitution of the Kingdom of Eswatini does not provide for the right to employment but makes provision for protection from slavery and forced labour. ${ }^{19}$ To tackle the problem of youth unemployment the government of Eswatini has adopted laws and policies that are relevant to youth employment in the past years. The Employment Act governs employee and employer relations including recruitment and dismissal and protection of wages. ${ }^{20}$

The country also adopted the Industrial Relations Act (IRA) and the Occupational Health and Safety Act in addition to the Employment Act which influences labour practice in Eswatini. For instance, the IRA is the main Act regulating collective bargaining on the terms and conditions of employment, as well as dispute resolution mechanisms, and other relevant matters. ${ }^{21}$ The law also deals whereas matters touching upon the safety and health of persons at work and in the workplace are regulated by the Occupational Health and Safety Act. ${ }^{22}$

In 1999 the Government of Eswatini adopted the National Development Strategy (NDS). The objectives of the NDS are to reduce poverty in Eswatini, promote the creation of jobs and gender equality, plus the delivery of a better quality of life for the people. The country also adopted a plan of action named the Poverty Reduction Strategy and Action plan which put the NDS aims and/or objectives into action, i.e. to reduce poverty by half in the year 2015 and have its overall elimination by the year $2022^{23}$. These two broader policy frameworks also address the issue of youth employment as a crucial area. These policies appear unlikely to reach their targeted outcomes by 2022 since youth unemployment and poverty continue to rise in the Kingdom.

The overarching policy framework for youth is the Swaziland National Youth Policy (SNYC), which alludes to youth employment. ${ }^{24}$ The youth policy calls upon the government to invest in an educational curriculum that meets the demands and/or requirements of the labour market. It further calls for the development of a youth service scheme which will serve the purpose of enabling young people to gain the required skills. The SNYC envisages the expansion of public works and infrastructure projects so that they provide youth with decent work. It also talks to the issue of opening the doors of

19 Sec 17 of the Constitution of the Kingdom of Eswatini, 2005.

20 The Employment Act of 1980, No. 5/1980.

21 The Industrial Relations Act (IRA) (No.1 of 2000) (as amended).

22 The Occupational Health and Safety Act (No 9 of 2001) (as amended).

23 The Swaziland Poverty Reduction Strategy and Action Plan (PRSAP) 2007 http: // www.tralac.org/files/2012/12/Final-Poverty-Reduction-Strategy-and-ActionPlan-for-Swaziland.pdf (accessed on 26 August 2018). 
education so that the youth can participate in technical and vocational education. It points to the need to regulate the wage system in the country so as to improve minimum wage, amongst other important provisions. There is no published data indicating whether the SNYC's implementation has resulted in a reduction of youth unemployment.

In addition to the national laws and policies, there are internationally driven frameworks such as the International Labour Organisation's Decent Work Country Programme for Swaziland and the African Union's Youth Charter which was ratified by Swaziland in 2013. The AYC makes provision for signatory states to invest in and empower the youth using: 'strategic approaches to youth employment, livelihood and skills development.'25

Article 15 of the AYC address specifically the youth employment question. ${ }^{26}$ It explicitly provides that young people have the right to gainful employment. It compels countries to have accurate data on youth employment, unemployment, and under employment so that the issue can be prioritised in national development programmes. The AYC provides for appropriate measures in article 15(4) that countries can adopt to ensure the realisation of the right to gainful employment by young people. For instance, countries which are signatories are to ensure equal access to employment and equal pay for equal work without any discrimination. ${ }^{27}$ Countries are urged to develop macroeconomic policies that focus on job creation for young people. ${ }^{28}$ Also, countries are to foster greater linkages between the labour market and the education system to ensure alignment to the needs of the labour market and youth employability. ${ }^{29}$

The ILO's Decent Work Country Programme for Swaziland makes provision for a number of key programmatic outputs such as:

to put in place policies promoting the creation of jobs for the youth, for women and for Swazi citizens as that would be likely to have the greatest impact on unemployment and poverty. ${ }^{30}$

and these outputs are in line with the Swazi National Development Strategy and the UN Development Assistance Framework. There is not much-written evidence to assess whether the internationally driven policies are being implemented in Eswatini and to gauge the degree to which they have improved the experiences of the youth in the labour market thus far. 


\subsection{Laws and policies on youth employment in South Africa}

South Africa has tackled the issue of youth unemployment through laws, policies, and programmes on youth employment. The South African Constitution No. 108 of 1996 makes no mention of employment as a right but instead provides in section 13 that a person may not be subjected to slavery, servitude or forced labour.

The constitution further provides for the freedom of trade, occupation and profession in section 22 as follows: 'Every citizen has the right to choose their trade, occupation or profession freely. The practice of a trade, occupation or profession may be regulated by law. 31

Section 23 provides that everyone has the right to fair labour practices. 32

The are other statutory laws touching on employment in the Republic such as the Basic Conditions of Employment Act (BCEA) ${ }^{33}$. The BCEA is not youth specific, it applies to all workers. It lays down minimum and maximum standards that must be complied with by the employers. ${ }^{34}$ The Act applies to all employment establishments and employees, excluding members of the National Defence Force, the National Intelligence Agency, the South African Secret Service; and unpaid volunteers working for charitable organisations.

Another statute regulation employment in South Africa is the Labour Relations Act (LRA). ${ }^{35}$ The LRA's stated purpose is to advance economic development, social justice, labour peace and the democratisation of the workplace in South Africa. Amongst other things, the LRA provides for employees' right to freedom of association, collective bargaining and the right to strike and recourse to lockout. 36

The Occupational Health and Safety Act, is another legislation touching on employees in the Republic. ${ }^{37}$ The Occupational Health and Safety Act provides for the health and safety of persons at work and in connection with the use of plant equipment and machinery; protection against hazards to health and safety arising from activities of people at work; and the establishment of an advisory council for occupational health and safety. ${ }^{38}$

The Basic Conditions of Employment Act 75 of 1997.

S Kopel Guide to Business Law - Commercial Law (2017) 350.

The Labour Relations Act 66 of 1995.

Secs 4, 26, 35 \& 64 of the Labour Relations Act 66 of 1995.

The Health and Safety Act 85 of 1993.

Kopel (n 34) 355. 
Unemployment Insurance Act, provides for the establishment of a central fund administration, financed through compulsory contributions by employers, employees, and the State. ${ }^{39}$ In terms of the Act, the employer is to contribute $2 \%$ of the employee's remuneration of which $1 \%$ comes from the employee and the other from the employer. ${ }^{40}$ This Act is also not youth specific but applies generally to a selected category of employees. To reinforce this Act the Unemployment Insurance Contribution Act was promulgated in $2002 .{ }^{41}$ This Act creates a duty on every employer to whom it applies to make contributions to this insurance fund monthly. ${ }^{42}$ Almost all employees are required to become contributors and may be eligible to claim unemployment benefits. Again this Act is not youth specific and addresses the issue of the unemployment insurance fund generally.

There is also the Skills Development Act (SDA) which has the objective of ensuring that in the labour market the levels of investment in education and training are increased. ${ }^{43}$ In terms of this Act, there is an expectation placed on employers to create new opportunities for employees to acquire new skills, to assist those entering the labour market for the first time gain work experience, as well as to hire those persons who struggle to find gainful employment. ${ }^{44}$ Therefore, the SDA makes it essential that employees get the opportunity to be upskilled through participation in learnership and other training programmes. ${ }^{45}$ It can rightly be inferred that this Act directly or indirectly addresses the issue of youth employment in South Africa.

The Employment Equity Act (EEA) is another statute that deals with the issue of employment in South Africa. ${ }^{46}$ The aims of the EEA are to promote equal opportunity and fair treatment in employment whilst ensuring the elimination of unfair discrimination. ${ }^{47}$ Youth unemployment, when it is systematic can be viewed as unfair discrimination, and this Act may be used to challenge it.

A closer look at youth-specific policies shows that the government of South Africa has been tackling the problem of youth unemployment. At the heart of policies on youth employment is the National Youth Policy. It recognises youth unemployment as a major challenge. Other policies are viewed to be inefficient in addressing

The Unemployment Insurance Act 63 of 2001.

Kopel (n 34) 357

The Unemployment Insurance Contribution Act 4 of 2002.

Kopel (n 34) 357.

The Skills Development Act 97 of 1998.

Kopel (n 34).

As above.

46 The Employment Equity Act 55 of 1998.

47 Kopel (n 34) 380. 
the demand for youth employment with Motlalepula Mmesi commenting that:

Top-down initiatives such as the government's Extended Public Works Programme (EPWP), launched in 2004 and sold to the public as a means of short to medium-term labour absorption and income generation for poor households, have proven they cannot adequately address youth unemployment. ${ }^{48}$

However, all is not lost as there are still government policies which are seen as confronting the plight of youth head-on such as the Youth Enterprise Development Strategy (YEDS). ${ }^{49}$ The YEDS is a programme solely aimed to encourage youth self-employment and youth-owned and managed enterprises. In essence, top-down government job creation schemes have proven ineffective in South Africa and in other SADC countries like Eswatini.

\section{International, regional and sub-regional legal framework on youth employment}

\subsection{International Level}

Both Eswatini and South Africa have ratified international treaties which promote and protect access to employment. The international legal framework comprises of both, binding and non-binding frameworks on either, labour issues in general or youth employment specifically. These include the International Covenant on Civil and Political Rights (ICCPR), 50 and the International Covenant on Economic, Social and Cultural Rights (ICESCR). ${ }^{51}$ The ICCPR outlaws slavery, providing that no person maybe help in slavery and slavetrade. ${ }^{52}$ It further prohibits that a person be held in servitude. ${ }^{53}$

The right to work, is found in article 6 of the ICESCR where state parties recognize the right of everyone to have the opportunity to gain a living by work which he or she freely chooses and/or accepts, as well as to take reasonable steps to safeguard the right. ${ }^{54}$ The

48 M Mmesi, 'South Africa's youth unemployment problem: What we need to know' (28th May 2015) http://www.polity.org.za/article/south-africas-youth-unemploy ment-problem-what-we-need-to-know-2015-05-28 (accessed 14 November 2017).

49 The Department of Trade and Industry Youth Enterprise Development Strategy (YEDS), a programme launched in November 2013.

50 ICCPR, adopted and opened for signature, ratification and accession by General Assembly resolution 2200A (XXI) of 16 December 1966, entry into force 23 March 1976.

51 The International Covenant on Economic, Social and Cultural Rights (ICESCR) was adopted and opened for signature, ratification and accession by General Assembly resolution 2200A (XXI) of 16 December 1966 entry into force 3 January 1976.

52 Article 8 of the ICCPR.

53 As above.

54 Article $6(1)$ of the ICESCR. 
Covenant enjoins state parties, to take the following steps to achieve the full realization of this right:

technical and vocational guidance and training programmes, policies and techniques to achieve steady economic, social and cultural development and full and productive employment under conditions safeguarding fundamental political and economic freedoms to the individual. ${ }^{55}$

The ICESCR does not end there, but goes on to provide that the state parties to it recognise:

the right of everyone to the enjoyment of just and favourable conditions of work which ensure, in particular; fair wages and equal remuneration for work of equal value without distinction of any kind, with equal pay for equal work, and a decent living for themselves and their families; ${ }^{56}$ safe and healthy working conditions; 57 equal opportunity for everyone to be promoted in his employment to an appropriate higher level, subject to no considerations other than those of seniority and competence; ${ }^{58}$ and rest, leisure and reasonable limitation of working hours and periodic holidays with pay, as well as remuneration for public holidays. ${ }^{59}$

Eswatini ratified both the ICCPR and the ICESCR in 2004, whereas South Africa, ratified the ICCPR in 2002 and the ICESCR instruments in 2015. Despite the above provisions by the instruments, both countries are grappling with unemployment challenges, particularly those concerning the youth. This is despite the fact that both countries have ratified and signed all major Conventions by the International Labour Organisation (ILO) as depicted in the ILO's Decent Work Country Programme for Swaziland (2013 - 2015) and the ILO's Decent Work Country Programme for South Africa (2014).

\subsection{Regional Level}

Both Eswatini and South Africa have ratified the African Charter on Human and People's Rights (herein referred to as the African Charter), in 1995 and 1996 respectively. ${ }^{60}$ The African Charter also known as the Banjul Charter provides for the right to access work in article 15 that every person has the right to work under favourable and satisfactory conditions and receive equal pay for equal work. ${ }^{61}$

It further stipulates that one of the duties of the person is chief of which to work to the best of his or her abilities and competence, as well as to pay taxes. ${ }^{62}$ Even though it is not clear what the intention

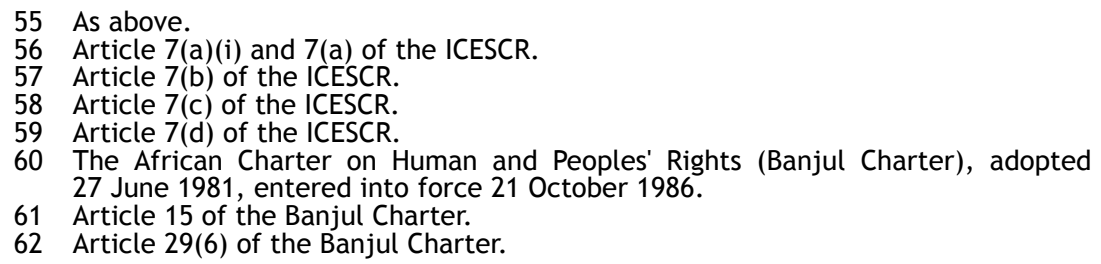


of this proviso is, it can be inferred that for the individual to be able to uphold his or her duties, he or she needs an enabling environment to gainful employment and/or entrepreneurship.

The AYC which is the major document offering blueprints on the rights of young people to access gainful employment, provides for sustainable livelihoods and youth employment. ${ }^{63}$ The AYC categorically provides for every youth to have the right to gainful employment. ${ }^{64}$ It further implores member states to conduct research and look into youth employment, unemployment and underemployment so as to ensure the availability of accurate data on the issue. This is to be done in order to ensure that there is a prioritisation of the issue in national development policies and programmes backed by clear and succinct programmes to address youth unemployment. ${ }^{65}$ Be that as it may, the challenge with the AYC is that it is a policy framework which countries must utilize for their purpose.

It must be noted that despite, the adoption of legal, policy, and programme frameworks at both national and international level, both Eswatini and South Africa's youth unemployment continues to increase at an alarming rate. The search for alternative solutions to curb youth unemployment facing the two countries remains alive. Perhaps business's corporate social responsibility, if strategically harnessed, can be one of the ways which can help reduce or even halt the increasing statistics on youth unemployment. Corporations exist within communities. Communities in crisis are akin to businesses in trouble. Since the existence and profitability of a corporation is dependent on the surrounding communities at large, discussed below are ways used by the two countries to ensure that corporations play their part.

\section{Corporate Social Responsibility and human rights}

The definition of CSR that is adopted for this paper is that provided by the World Business Council for Sustainability Development (WBCSD) as

the continuing commitment by business to behave ethically and contribute to economic development while improving the quality of life of the workforce and their families as well as of the local community and society at large. ${ }^{66}$

63 Article 15 of the AYC.

64 Article 15(1) of the AYC.

65 Article 15(3) of the AYC.

66 FASSET Corporate social responsibility course handbook (2012) 3. 
According to the above entity, CSR is an ethical approach in which a company voluntarily contributes towards the betterment of society. ${ }^{67}$ According to Ally, CSR deals with the integrity of the company as an institution, the mission, values, and the impact the company has on the community as opposed to corporates spending funds and expertise. ${ }^{68}$ It is something more than philanthropy.

Over the years, human rights have featured as an important aspect of CSR. This is evidently seen in the adoption of the United Nations (UN) Guiding Principles on Business and Human Rights (also known as the Ruggie principles). The principles guard against possible negative human rights impacts by business and describe what companies and governments should do to avoid and address them. ${ }^{69}$ The Ruggie principles in this regard postulate the following:

(a) States' existing obligations to respect, protect and fulfil human rights and fundamental freedoms;

(b) The role of business enterprises as specialized organs of society performing specialized functions, required to comply with all applicable laws and to respect human rights;

(c) The need for rights and obligations to be matched to appropriate and effective remedies when breached. ${ }^{70}$

The above text resonates with the arguments in favour of CSR as alluded to by writers such as Ally, who is of the view that it is typical of CSR norms, to be aligned with the belief that it is in the best interest of corporations to be socially responsible. ${ }^{71}$ The writer further bases his assertion on the premise that taking care of the environment and communities where they operate by the present generation of corporates will yield good results in the long-term sustainability of their business. ${ }^{72}$ Indeed, this will be in the best interest of corporations as sustainability is regarded as a process whereby the present generation takes care of their needs but is also mindful of the needs of the future generations.

The author Fig, argues that business in South Africa has avoided CSR, despite the wide use of the term among practitioners and academics, in favour of concepts such as corporate social investment and corporate citizenship. ${ }^{73}$ According to the author, the two

67 As above.

68 S Ally 'Corporate social responsibility: Practices, trends and developments' LLM Thesis, University of Cape Town 2013 at 13.

69 Ally (n 68) 23-24.

70 Guiding Principles on Business and Human Rights (Ruggie Principles): Implementing the United Nations 'Protect, Respect and Remedy' Framework, endorsed by the Human Rights Council through resolution 17/4 of 16 June 2011.

71 Ally (n 68) 37.

72 As above.

73 D Fig Manufacturing amnesia: Corporate social responsibility in South Africa In critical perspectives on corporate social responsibility International Affairs Royal Institute of International Affairs (2005) at 599. 
concepts ask no questions about legacy, memory, history, justice, or moral and ethical responsibilities. ${ }^{74}$ The author affirms that even though the concepts project ideas of good practice, neither really assign to firms any moral or ethical responsibility for past malpractice. He avers that under these concepts there is little acknowledgement of the legacies of social and environmental injustice perpetrated by business under apartheid. ${ }^{75}$

Fig further observes that businesses have responded in different ways to perceived state failure or incapacity to address major social issues adequately. ${ }^{76}$ He highlights the contributions made by business in combating crime in South Africa through the formation of a coalition entitled 'Business Against Crime'. The author further alludes to the fight against HIV, stating that while the government was debating about the toxicity of the treatment, the business sector had already begun to provide HIV-infected workers with anti-retroviral drugs. ${ }^{77}$ These are just a few examples of the many contributions to the protection of human rights in South Africa by the business sector.

It must be noted that business in South Africa have acted in line with the Ruggie principles in their involvement with alleviating social challenges. In principle 15 of the Ruggie Principles, businesses are urged to adopt policies and have processes in place that are commensurate with their size. This would ensure that they meet their responsibility to uphold human rights in communities where they operate. The principles call for:

A policy commitment to meet their responsibility to respect human rights; A human rights due diligence process to identify, prevent, mitigate and account for how they address their impacts on human rights; Processes to enable the remediation of any adverse human rights impacts they cause or to which they contribute, amongst others. ${ }^{78}$

The Ruggie Principles dictate that business enterprises have the responsibility to respect human rights at all times. Hence, businesses are called upon to adopt the appropriate policies and processes. Moreover, principles 16 to 24 stipulate that business enterprises need to know and show that they respect human rights. This can effectively be done when there is in place policy commitment. In carrying out human rights due diligence, business enterprises can be able to identify, prevent, mitigate and account for how they address their adverse human rights impacts. ${ }^{79}$

Recently scholars have successfully argued that CSR can be used address challenges associated with the attainment of socio-

74 As above.

75 Fig (n 73) 601

76 Fig (n 73) 608.

77 Fig (n 73) 610.

78 Principle 15 of the Ruggie Principles (n 70).

79 Principle 17 of the Ruggie Principles (n 70). 
economic rights. Socio-economic rights in recognition of international law originate from the International Covenant on Economic, Social and Cultural Rights (ICESCR) and are rights which are regarded as second generation rights. ${ }^{80}$ This means that these rights impose a positive duty on the state to act, or at least create conditions necessary for citizens to have access to facilities which are considered essential for modern life. ${ }^{81}$

As alluded to above the right to work is provided by the ICESCR. ${ }^{82}$ It must be noted that the positive obligation to create jobs for the youth rests primarily on governments. However, this paper argues that through engaging CSR, corporations too, have a role to play in the protection of human rights such as the right to gainful employment. For instance, Obisanya argues that CSR can be used to claim for the following socio-economic rights: 'right to adequate housing, health care, water and social security, clean environment and finally right to education. 83

It is the contention of this paper that Obisanya is accurate in his assertions and that by extension, CSR can address claims for the socioeconomic right known as the right to work and or right to gainful employment. Below the paper looks at some of the laws and policies on CSR that have been adopted by both countries to provide for youth employment, if any.

\section{Laws and policies on CSR}

Even though CSR is a topical issue usually reserved for discussion under corporate governance, in Eswatini, the main legislation regulating corporates namely, the Companies Act of 2009, makes no direct or indirect reference to corporate social responsibility. The same can be said about South Africa's Companies Act 71 of 2008. The Acts do not impose a duty or obligation on companies to engage in CSR activities or projects in order to uplift the communities where they operate. It is other government laws and policies which directly or indirectly hint on CSR in South Africa together with King III Code on Corporate Governance, which is a soft law on ethical leadership and corporate citizenship which applies to businesses globally. As a result, many corporations have taken part in some form of CSR in both countries.

80 JC Mubangizi The protection of Human Rights in South Africa - A legal and practical guide (2013)11.

81 As above.

82 Article 6 of the ICESCR.

83 TA Obisanya 'Philanthropic corporate social responsibility as a tool for achieving socio-economic rights in South Africa' LLM thesis, University of Venda, 2017 at 4. 


\subsection{CSR in Eswatini}

It appears that there is no concerted effort from the government to make CSR compulsory for businesses in the country, as there is no law or policy regulating and directing business on CSR. As such companies choose for themselves whether to opt for CSR and if so, to which area or sphere they would like to direct their corporate responsibility. Many companies in the Kingdom have directed CSR to events that would promote their image or indirectly advertises their services. Hence the major football league in Eswatini is sponsored by big companies such as MTN and corporate banks. Kabir and another are of the view that CSR as a concept for Eswatini's companies is fairly new and that only a handful of them disclose CSR information in their corporate reports. ${ }^{84}$ It is common practice in Eswatini to see companies devoted to CSR concentrating on sports and beauty pageants and very few concentrate on funding causes which are socioeconomic rights oriented such as, education and community development projects and youth employment in particular.

In essence, companies do as they please when it comes to adhering to CSR. However, there are companies seen to be adhering to their CSR responsibilities despite the fact that there is no policy directing them on how to go about it. For instance, the Swaziland Sugar Association (SSA), provides in its annual integrated report of 2011/12 that the company adheres to the King III Code on Corporate Governance. ${ }^{85}$ The company's website states that for SSA corporate responsibility is informed by the company's aims and is committed to providing a relevant and meaningful social investment programme which contributes to the sustainable social development of Eswatini. ${ }^{86}$ Accordingly, corporate social investment (CSI) is an integral part of SSA's commitment to sustainable development in the country as evidenced by its annual budget. Furthermore, the company recognises that CSI is its gateway to the primary terrain for branding and enhancing the organization's reputation as a responsible corporate citizen and a caring partner within communities where the sugar industry operates. 87

It is of absolute importance that companies involved in CSR/CSI do so in collaboration with others. This is what is currently being carried out by SSA. For instance, the company stipulates that where it lacks the certain competence to deliver on CSI, it collaborates with other

$84 \mathrm{MDH}$ Kabir 'Corporate social and environmental accounting information reporting practices in Swaziland' 8(2012) Social Responsibility Journal at 156.

85 Swaziland Sugar Association (SSA) Annual report 2011/2012 http://www.ssa. co.sz/images/stories/financials/SSAAnnualreport2012.pdf (accessed on 14 July 2018).

$\frac{86}{87}$ http://www.ssa.co.sz/social-responsibility/ (accessed on 14 July 2018).

87 As above. 
organisations with which they share common values so that they form a mutually beneficial partnership in order to achieve their CSI jointly to the betterment of the communities they are serving. ${ }^{88}$

SSA has tackled socio-economic rights through their CSI policy implementation. This is because SSA is currently focusing on activities which are part of socio-economic rights directly and indirectly. For instance SSA addresses the issue of youth employment supporting financially rural primary education; capacity building and skills development for rural communities on one hand. ${ }^{89}$ On the other hand, SSA supports health-care in and environmental preservation. ${ }^{90}$ The company plays a role in national disaster relief programmes and activities aimed at vulnerable groups of the community (e.g. elderly, disabled, orphans). ${ }^{91}$ It has been involved in the development of sports; and self-empowering programmes as for the youth, women and people with disabilities. ${ }^{92}$

Since the government is not involved, one has to commend the company for having a CSR policy document that primarily addresses issues of socio-economic rights and youth empowerment and employment. This goes to prove that indeed businesses in Eswatini can engage in the promotion, protection and fulfilment of human rights. It shows that the adoption of CSR policy statements by companies can be harnessed to serve not only as a mere public relations strategy but as a vehicle that delivers on the protection of socio-economic rights as well as, the right to employment, in particular, youth employment.

The issue that remains is accountability with regard to the issue as to whom a company is accountable for ensuring that their CSR policy is indeed benefiting the real needs of the community, such as to curb youth unemployment. The company self-regulates its CSR which is very problematic hence, this paper argues that the government of Eswatini should step in and call corporations to account on their implementation of CSR.

However, the government has no instrument which entitles it to demand accountability from companies. Solace and remedy lie in the John Ruggie Principles on Business and Human rights, which call on states to promote, protect, and fulfil human rights and fundamental freedoms. ${ }^{93}$ Eswatini can comply by putting in place laws and/or policies to gentle nudge businesses to do the right thing because as revealed by the SSA case, businesses are likely to respond to socio-

92 As above.

93 As discussed above (n 70). 
economic rights challenges/problems facing communities. Also, the Ruggie Principles call on businesses to comply with all applicable laws and to respect human rights, something which is not hard for business to follow as most of them are creatures of statutes and or laws, as their very existence is as a result of following the country's laws. ${ }^{94}$

\subsection{CSR in South Africa}

Despite the fact that the Constitution of the Republic of South Africa, 1996 and the 2008 Companies Act do not have any reference to CSR, there are laws and policies in South Africa addressing CSR, unlike in the case of Eswatini. These laws are, the Companies Regulation 2011, the Broad-Based Black Economic Empowerment Act, 2003 and the Employment Equity Act, 1998. ${ }^{95}$

It must be pointed out at the outset that the EE Act is only binding on businesses that employ above 50 employees or companies within the Agricultural industry with a yearly revenue greater than R2 million. ${ }^{96}$ The Act provides that businesses formulate a work-place equity policy mapping the corporations' strategy to ensure occupational parity and render a year on year account of its developments in this respect. ${ }^{97}$ The EE Act in section 24(1) gives a directive to businesses to designate one or more high-ranking administrators to assume the function of effecting and supervising the equity strategy. ${ }^{98}$ However, for the purposes of tracking compliance in as far as employment equity is concerned, there is sadly no provision for a committee which will monitor and report on the same. ${ }^{99}$

A closer look at the Broad-Based Black Economic Empowerment Act, which came about as a means to comply with the BEE Act has resulted in many companies being legally compelled to adhere to CSR initiatives. ${ }^{100}$ The Act requires corporations and/or business enterprises based in South Africa to engage in Preferential Procurement Policy, so as to assist previously disadvantaged groups and communities who were excluded in the economy, to be actively involved in the country's economy. ${ }^{101}$ This is one way the government of South Africa has addressed the imbalances of the past, and it may

94 As above.

95 These laws are extensively discussed in pages 7 and 8 of this paper above.

96 Obisanya (n 83) 43.

97 Sec 20 of the Employment Equity Act 55 of 1998. It stipulates the objectives to be reached for each year of the plan (sec 20(2)(a)) together with the procedures to be followed in order to monitor and evaluate the progress of the plan (sec 20(2)(f)).

98 As above.

99 Obisanya (n 83) 98.

100 The Broad-Based Black Economic Empowerment Amendment Act, 2013.

101 FASSET (n 66) 9. 
be argued that they have thereby addressed one aspect of human rights for those people through indirectly engaging CSR.

Furthermore, the Act establishes a national framework for the promotion of BEE through the establishment of the Black Economic Empowerment Advisory Council, which shows that the government is serious about accountability as this Council was created to hold businesses accountable in their adherence to CSR. ${ }^{102}$ In addition, the Act compels the Minister responsible in the implementation of the black economic empowerment initiative, to issue codes of good practice to companies which are part of the BEE initiative. ${ }^{103}$ The Minister must issue a scorecard to the companies to measure their accomplishments and encourage sector-specific BEE compliance, with the aims and objectives of the Act. ${ }^{104}$ Such a stance is in support of the argument that the government is nudging businesses to address issues of human rights. Critics point out that the initiative has not been handled well, however, if the BEE initiative had been properly implemented, it could have been one of CSR's examples in dealing with human rights to empower people and local communities. ${ }^{105}$

Another component of CSR dealing with human rights is found in the Companies Regulation of 2011. The regulation compels certain companies to have Social and Ethics Committees (SEC) state-owned company. ${ }^{106}$ It calls upon corporations to establish SECS, and the SEC has the mandate to monitor corporate governance and to oversee the implementation of philanthropic and/or CSR projects. ${ }^{107}$

In conclusion, one can safely adduce that South Africa has a plethora of law and policies in place to encourage businesses to fully participate in CSR initiatives that address the main argument of this paper, youth unemployment. However, as critics correctly object, the operationalisation of such initiatives which have prospects of supporting youth employment are frustrated by mismanagement and lack of correct implementation.

\section{CSR advancing youth employment as a human right}

The AYC has already made the call that every young person shall have the right to gainful employment, and governments have been called

106 Sec 26 (2) of The Companies Regulation of 2011.

107 As above. 
upon to take all appropriate measures with a view to achieving the full realisation of this right. ${ }^{108}$ The statistics presented for both countries under investigation here have shown that these countries are grappling with youth unemployment despite putting in place laws and policies aimed at curbing youth unemployment.

In the case of South Africa CSR has been used to address some of the historical imbalances which was caused by racial inequality in South Africa. This is evidenced by the provisions of the BEE Act, and the EE Act, which are aimed at economic empowerment of blacks including youth and eliminating unfair discrimination in the workplace, respectively. In the case of Eswatini, CSR is being adopted by businesses for the promotion of their own personal image and gain. These businesses can be called upon through a policy to direct their CSR to programmes which will, directly and indirectly, curb youth unemployment in Eswatini.

For instance, MTN Eswatini can decide to channel its philanthropic CSR investments to rural schools in Eswatini so that they have libraries and laboratories. That would go a long way in ensuring that students from rural communities also have access to quality education, which will then lead them to having access to gainful employment.

CSR directed to education is much needed in Eswatini considering that, even though the Constitution of the Kingdom of Eswatini, 2005 provides for free primary education, the government of Eswatini was reluctant to provide for it. In the case of Swaziland National ExMiners Workers Association $v$ The Ministry of Education and Others, the government was taken to court for the endorsement of the right to free primary education. ${ }^{109}$ However, the court made the right to be subject to progressive realisation, something which was against international norms. ${ }^{110}$

In order for these rights to be realised, there is a need for a monitoring or regulating body to ensure that businesses are focusing CSR to where it is needed most which is to curb youth unemployment. According to author Fig, in South Africa, the regulatory functions of the state are relatively well developed, with the exception of certain aspects of environmental governance. ${ }^{111}$ He makes the example of BEE and argues that it is an area where the state has used its authority to urge business to act in line with government policy and address certain social ills. ${ }^{112}$ He points out that the government, labour and business have agreed to be bound by the terms of the BEE Charter. ${ }^{113}$

108 Article 15 of the AYC.

109 Swaziland National Ex-Miners Workers Association $v$ The Ministry of Education and Others (2168/09) [2010] SZHC 258 (19 January 2010).

110 A Skelton \& SD Kamga 'Broken promises: Constitutional litigation for free primary education in Swaziland' 3(2017) Journal of African Law at 419.

111 Fig (n 73) 606.

112 As above 
The Charter lays out for businesses specific targets for transformation to take place in spheres such as ownership, employment, tender and procurement processes, and promotion and training opportunities, as well as local economic development. ${ }^{114}$

South Africa has made a good attempt to align CSR with the realisation of human rights. There is a need to shift their focus from the injustices of the past and take concrete actions to address the injustices of today, particularly youth unemployment. However, in the case of Eswatini, there is little evidence suggesting that there is a policy directive on how businesses should engage CSR. Therefore, in Eswatini, business enterprises are to adhere to the Ruggie Principles and adopt CSR policies and/or programmes that will make a significant contribution to their development and or human rights. Nevertheless, there are exceptions as it was revealed that some companies, albeit a few, appear to be adhering to the CSR call such as SSA and are making small inroads in tackling youth empowerment and employment in Eswatini. ${ }^{115}$

Such initiatives by corporations are laudable because they empower the youth with job prospects in the future and job opportunities in the present time. The job prospects would be a step towards empowering future leaders' as they are sometimes referred to. ${ }^{116}$ This paper argues that for every young person, a job prospect and opportunity ensures that the youth's dignity is safeguarded and that he or she will be dissuaded from frustrations which might lead to delinquency, and or abuse of illegal substances, such as drugs. Also, a CSR initiative that eradicates youth unemployment has a good impact on communities in that, youth employment is seen as a glue that facilitates social integration, intergenerational dialogue, citizenship and solidarity.

The youth forms the majority of the population in the two countries studied here, hence it is inconceivable that the largest proportion of the society is being side-lined intentionally, or unintentionally. This paper has successfully argued that businesses and human rights are not mutually exclusive, but in fact, businesses have a responsibility to respect and promote human rights where they operate. It was pointed out that socio-economic rights, in particular, the right to employment, can be addressed through the adoption of CSR initiatives. In order for that to happen, governments and

113 Fig (n 73) 607

114 As above.

115 Swaziland Sugar Association (SSA) Annual report 2011/2012 http:// www.ssa.co.sz/images/stories/financials/SSAAnnualreport2012.pdf (accessed on 14 July 2018). See also SSA's contribution to CSR in Eswatini is discussed on page 18 of this article.

116 The Swaziland state of the youth report, 2015 https://swaziland.unfpa.org/sites/ default/files/pub-pdf/Youth\%20Report\%202015\%20with\%20covers.pdf (accessed 15 September 2018). See also the South African National Youth Policy 2015 - 2020. 
businesses ought to work together. If the governments and businesses of the two countries fail to forge a way of curbing or halting the growing youth unemployment challenge, there will be huge ramifications in terms of economic growth, crime, political instability, drug abuse, and other social challenges.

\section{Conclusion}

This paper has looked at the situation of youth unemployment in both Eswatini and South Africa and it was found to be high. It was observed that there are many causes for the soaring numbers of youth who are unemployed. The legal and policy framework for both countries targeting youth employment were investigated and it was found that most of the laws are not youth specific and that policies that have been put in place by the government to target youth employment take a top-down approach and have not yielded much of the results which were anticipated. The international legal framework on employment was also investigated.

In this paper, the AYC was used as the benchmark to advance arguments necessary for young people to have access to gainful employment in Eswatini and South Africa. It was revealed that there were no laws and/or policies directly mandating the use of CSR by businesses in Eswatini, whereas in South Africa, CSR initiatives are compulsory for some business enterprises. However, the implementation of CSR in SA is fraught with challenges. The paper has successfully argued that the interests of the youth will be better served if governments and the business sector collaborate. 